\title{
Interpretacje
}

\section{SOLIDARNOŚĆ JAKO PIĘKNA PAMIĄTKA}

\author{
PAWEŁ KUCZYŃSKI \\ Zespót ANALIZY Ruchów SPOŁECZNYCH \\ mail: pawel.kuczynski@gmail.com \\ ORCID: https://orcid.org/0000-0003-3819-2346
}

\section{SOLIDARITY AS A BEAUTIFUL MEMORABILIA}

I have written this reflection as both, a social movement researcher and a Polish citizen at the same time. The text is the analysis of the uses and abuses made not only by politicians who have interpreted Polish history of the eighties, but also, by the leading trade union who defines itself as the only successor of Solidarity, while in fact, Solidarity in the eighties was not only a trade union. It was a total, three-dimensional social movement encompassing citizens, workers and independence. Thanks to this unique synthesis, there took place a great breakthrough which covered not only Poland but also the whole soviet camp.

Growing amnesia forces us to put the question: who, in todays' reality, needs a real memory of Solidarity's input to Polish history? Answering this question it is worth to exclude political parties and their allies fighting for power. It is fascinating to observe how contemporary Polish society is changing and what are the scopes of discussion among the new political actors emerging every year. Naturally, the focus is more on the future than on the past. The heritage of Solidarity wanes gradually but still remains alive among some of social milieu composed of three different groups: the biggest one is old Solidarity militants looking behind with melancholy and bitterness, the second are young leaders of new social movements who are conscious of the historical role of Solidarity as a social movement as well as the differences between the old and new times. Last but not least we should remember about the new generation of scientists who are focused on Solidarity phenomenon. Most of them are historians rather than sociologists.

\section{Keywords}

Solidarity, social movement, heritage, leaders, trade union 
Za prawowitego spadkobiercę „Solidarności 1980-1981" uważany jest i sam się uważa związek zawodowy NSZZ „Solidarność”. Władze związkowe co pewien czas przypominają o tym, że tylko one legalnie dysponują logotypem i nazwą Solidarności. Nie każdemu pozwalają z tego źródła czerpać, czego doświadczyli na przykład organizatorzy obchodów rocznicowych w sierpniu 2017 roku.

Powszechnie jednak wiadomo, że Solidarność była ruchem społecznym, a więc czymś więcej, niż związkiem zawodowym. To mocno komplikuje problem schedy po Solidarności. Wszakże ruch społeczny, poza kluczowym nurtem związkowym, miał w sobie inne logiki działania, które dzisiaj ocenilibyśmy jako wręcz wykluczające się nawzajem. W drugiej połowie 1981 roku polsko-francuski zespół, kierowany przez Alaina Touraine’a i Jana Strzeleckiego, przeprowadził badania ruchu społecznego Solidarność metodą interwencji socjologicznej. Główny wniosek z nich płynący, mówiąc w uproszczeniu, był następujący: wielki ruch społeczny swoją tożsamość i skuteczność zawdzięczał połączeniu trzech logik działania: związkowej, obywatelskiej i narodowej. Polacy walczyli o prawa pracownicze i obywatelskie, aż do później jesieni 1981 roku skutecznie trzymając w ryzach pogłębiające się różnice pomiędzy różnymi ugrupowaniami.

Po 38 latach, trzy wspomniane nurty ruchu społecznego konkuruja o prawo do dziedziczenia legendy Solidarności. Mamy więc najnowszą odsłonę polityki historycznej i to w odniesieniu do historii najnowszej. W walce o rząd tych polskich dusz, dla których (jeszcze) ważna jest Solidarność, związek zawodowy nie miesza się do obywatelskich akcji, które nasiliły się w Polsce, począwszy od STOP ACTA w 2012 roku. Nie ma watpliwości, że czerwono-biała etykieta wyblakła, dla partii politycznych ma malejące znaczenie, świadków ubywa, a młode pokolenia ma swoje własne symbole. Przy czym legenda Solidarności lepiej się ma za granicą niż w Polsce.

\section{Komu jest dzisiaj w Polsce potrzebna Solidarność?}

Jeśli celowo pominiemy „nas wszystkich”, o których toczą bój partie polityczne, to pozostaje otwarty katalog różnych grup społecznych. Można przeprowadzić badania opinii, aby się dowiedzieć, czy i jak pamiętają Solidarność wielodzietne rodziny, młodsi i starsi robotnicy, mieszkańcy wsi albo nauczyciele. Taki archipelag grup można dowolnie wydłużyć, pamiętając o tym, że poważne dyskusje dzisiaj toczą się wokół europejskiej solidarności ${ }^{1}$, a nie ruchu społecznego Solidarność.

Hipotetycznie można wskazać w Polsce trzy grupy, dla których pamięć o Solidarności jest nadal ważna. Pierwsza $z$ nich to to dawne kadry NSZZ Solidarności, czyli ówcześni działacze szczebla zakładowego. Druga, to liderzy żywych w Polsce ruchów społecznych². Wreszcie

\footnotetext{
${ }^{1}$ Por. Solidarność i kryzys zaufania, red. J. Kołtan, Gdańsk 2014.

${ }^{2}$ Oczywiście nie tylko w Polsce, na co jest wiele dowodów. Można bez trudu udokumentować tezę, że siła tego sygnału płynąca z przeszłości jest trwalsza dla zagranicznego, aniżeli krajowego audytorium. W czerwcu 2017 roku miałem okazje rozmawiać z urodzonym na Wybrzeżu Kości Słoniowej obywatelem Francji, który był represjonowany w swoim rodzinnym kraju. Przekonywał mnie, że Solidarność i Jan Paweł II były dla niego najważniejszymi drogowskazami.
} 
trzecia grupa to naukowcy i badacze, zwłaszcza historycy i socjolodzy. Być może od tych grup dzisiaj najbardziej zależy odpowiedź na pytanie: jaka pamięć o Solidarności trwa we współczesnej Polsce $^{3}$. Mam nieodparte wrażenie, że granica powszechnego zapomnienia są dwa pokolenia. Dzieci solidarnościowców mają dość swoich problemów, ale pamięć ojców trwa. Wnuki dorastają, więc można ich spytać, co wiedzą o najnowszej historii Polski. Obawiam się, że dla pokolenia Solidarności nie będzie to dobra wiadomość.

\section{Melancholia, czyli Solidarność w oczach dzia- łaczy zakładowych}

W badaniach socjologicznych skoncentrowanych na pamięci o Solidarności, jak te realizowane w Instytucie Socjologii UW lub przez Europejskie Centrum Solidarności (ECS) w Gdańsku, znajdziemy częściową odpowiedź na pytanie co przechowuja w zakamarkach pamięci zakładowi liderzy - zapomniani bohaterowie tamtych czasów. We tych wspomnieniach nie znajdziemy oczywiście jednej prawdy o tamtych czasach, choć niezmiennie przebija $z$ nich codzienny heroizm. Takie indywidualne opowieści są dostępne na stronie ECS jako „notacje video”, gromadzone obok klasycznych dokumentów historycznych. Te wspomnienia przypominaja powrót do pierwszej miłości, która jest trwałym śladem, coraz bardziej czystym i wyraźnym pomimo upływu lat.

Działacze zakładowi byli „solą ziemi” ruchu społecznego. Nie tylko oni przyznają się, że za- kochali się w „Pannie S”, tak jak Krzysztof Kelus w 1982 roku $^{4}$. Niestety ta miłosna historia jest jedyną wspólną prawdą dzisiejszych emerytów i rencistów. Można do niej dzisiaj dopisać pompatyczny patriotyzm i budować na tym okolicznościowe akademie, co zauważyli działacze PiS i NSZZ „Solidarność”. Stało się to zbyt późno, ale wielu ludziom dało poczucie, że nie zostali zapomniani. Swoisty powrót na scenę działaczy, o których nie wolno było zapomnieć, okazał się złowieszczy dla elit politycznych, podkreślających swój solidarnościowy rodowód. Tak ówcześni zakładowi działacze, jak szeregowi uczestnicy Solidarności z wielkich zakładów przemysłowych potrzebowali zadośćuczynienia, sprawiedliwości, która o nich zapomniała. Powtarzali i powtarzaja nadal: „To oni wybili się na naszych plecach”. „To oni dorobili się naszym kosztem". Dla nich Lech Wałęsa jest kimś innym niż dla Micka Jaggera. Retoryka ruchu społecznego okazała się mniej nośna niż retoryka ruchu związkowego, którego zadaniem historycznym jest bronić pokrzywdzonych. Spojrzenie zapomnianych bohaterów tamtych czasów biegnie w przeszłość, a nie w przyszłość. Sa podatni na polską martyrologię.

\section{Akcja, czyli Solidarność jako punkt odniesienia polskich ruchów protestu}

W lutym i marcu 2012 roku Zespół Analizy Ruchów Społecznych przeprowadził badanie wśród liderów STOP ACTA. Zaskoczyło nas

\footnotetext{
${ }^{3}$ Tej kwestii najwięcej uwagi poświęcił Ireneusz Krzemiński i jego zespół. Por. I. Krzemiński, Solidarność - doświadcz̨enie ipamię́, Gdańsk, 2010.

${ }^{4}$ Piosenka Jacka Kaczmarskiego do słów Jana Krzysztofa Kelusa z roku 1982 miała następujący refren: „Nie była w pełni w moim typie - ale lubiłem to, że jest - trochę złośliwie ją nazwałem »Sentymentalna panna S.«".
} 
przywoływanie przez nich Solidarności, obok innych ruchów protestu jak Indignados czy Occupy Wall Street, które były bardziej aktualne i generacyjnie bliższe młodzieżowym liderom. Jednak uczestnicy STOP ACTA nawiązywali do ruchu społecznego Solidarność na swój sposób. Podkreślali, że ich jest inny, że ma odmienny charakter. Nie mówili o walce o władzę, tylko o zatrzymaniu ACTA. Solidarność była im bliska, ale mieli już swoje własne doświadczenia np. jako uczestnicy marszu niepodległości lub też właśnie je zdobywali w Siedlcach lub Krakowie. Deklarowali, że walczą o prawo do wolnego internetu i tworzyli własną opowieść.

Liderzy ruchów społecznych nawiązują do innych ruchów protestu. W ten sposób zdarza im się również odnajdywać sojuszników, w sensie faktycznym lub symbolicznym. Solidarność nie była „odnośnikiem historycznym” dla ruchów feministycznych, którego najważniejszą odsłoną we współczesnej Polsce był „czarny protest” w październiku 2016 roku. Kobiece ruchy emancypacyjne mają swoją znacznie dłuższą tradycję i wymiar ponadnarodowy, a rola kobiet w polskim ruchu 1980-1981 dopiero niedawno zaczęła być doceniana. Znacznie młodsze od feminizmu ruchy pokojowe, również nie doszukiwały się swoich korzeni w Solidarności, nad czym niegdyś ubolewał Timothy Garton Ash, pisząc, że „zachodni ruch pokojowy w żaden sposób nie powiązał swojej sprawy ze sprawą Solidarności" ${ }^{5}$.
Sięgając po inne przykłady warto zauważyć, że na przykład polski ruch nacjonalistyczny $i$ kibicowski, tworzony przez młode pokolenie i często utożsamiany z marszami niepodległości, nie nawiązuje do Solidarności jako dziedzictwa swoich ojców. Woli przywoływać pamięć swoich dziadków lub raczej pradziadków. Woli mówić o Żołnierzach Wyklętych niż o żołnierzach Armii Krajowej, choć trzeba przyznać, że poza antykomunistycznymi symbolami na tatuażach, ubraniach i sektorówkach pojawia się również Katyń i Powstanie Warszawskie.

Jeśli idzie o ruchy protestu z przeciwnej strony polskiej sceny politycznej, to w przypadku takich formacji jak KOD, Obywatele RP czy Akcja Demokracja raczej odchodzi się od Solidarnościowego mitu. Jest to powolny proces. O ile KOD jeszcze latem 2017 roku próbował korzystać ze wsparcia niektórych kluczowych działaczy Solidarności, jak Lech Wałęsa i Władysław Frasyniuk, to inne grupy obywatelskie okazały się w tym względzie bardziej powściagliwe. Na pewno wszystkie te inicjatywy obywatelskie usiłowały dystansować się od partii politycznych ${ }^{6}$. Dwie największe z nich mogą się jeszcze kojarzyć z dawnymi działaczami Solidarności, choć nie to dzisiaj decyduje o negatywnym nastawieniu do polityki w wydaniu partyjnym. Najbardziej widoczny w ostatnim czasie „ruch konstytucyjny”, który powrócił na scenę w czerwcu i lipcu 2018 roku, skutecznie uwolnił się od kłopotliwej obecności

${ }^{5}$ T. Garton Ash, Polska rewolucja Solidarność, Londyn 1987, s. 216.

${ }^{6} \mathrm{Na}$ demonstracji zorganizowanej pod Sejmem przez KOD w niedzielę 16 lipca 2017 roku, wbrew zapowiedziom, pojawili się - bodaj zaproszeni przez Władysława Frasyniuka - liderzy partii opozycyjnych. Cztery dni później, czyli 20 lipca, demonstracja pod Pałacem Prezydenckim została zorganizowana przez Platformę Obywatelska. 24 lipca Prezydent Andrzej Duda ogłosił zawetowanie dwóch z trzech ustaw, a o godzinie 18 przed jego siedzibą odbyła się demonstracja nowego typu. Nie prowadzili jej ani liderzy partii opozycyjnych, ani KOD, ani bohaterowie Solidarności. Miała charakter obywatelskiej inicjatywy i odbywała się pod hasłem „3 x VETO - Pod Pałacem Prezydenckim bez partyjnych liderów”. 
sztandarów partyjnych. Choć ponownie zaprosił na scenę profesora Adama Strzembosza, to był daleki od budowania swojego decorum w oparciu o symbole Solidarności ${ }^{7}$.

Jestem przekonany, że symbole Solidarności blakną, co wydaje się procesem naturalnym. W związku z tym warto zastanowić się nad tym, czy nieodwołalne zanikanie tych symboli nie pociaga za sobą zaostrzenia podziałów i konfliktów w Polsce. Czy w związku z tym imię zgody narodowej należy ratować pamięci o ruchu społecznym Solidarność, który jest ostatnim uświęconym symbolem jedności - narodowej i społecznej? Będzie bardzo trudno przekonać do tego młode pokolenie, nawet tę jego część, która organizuje ruchy protestu bliskie rządzacej ekipie jak ruchy Pro Life. Po prostu młodzi ludzie posługują się nowymi etykietami w opisie polskiego społeczeństwa. Masowe demonstracje w Warszawie, które miały miejsce latem 2017, zostały tak opisane przez anonimowego blogera: „Wlazłem w to stado niechcacy w ten weekend w Warszawie. Próbowałem przedostać się ze stacji Metra na Nowym Świecie pod Kolumnę Zygmunta. Zatroskani UBywatele i setki hipsterów na metr kwadratowy oblegało Krakowskie Przedmieście. Z troską w oczach i wkładami do zniczy z Biedronki witali kolejnych »zjednoczonych opozycjonistów«" .
Prawda, czyli świadectwa, badania i teorie na temat Solidarności

Intelektualiści bywają ludźmi idei. Niegdyś czerpali siły i nadzieję z Solidarności, którą wspierali. Dzisiaj do tych odległych czasów podchodza z większym dystansem i zwracają uwagę na własne umiejscowienie $\mathrm{w}$ polu sporu o niedaleka przeszłość 9 .

Kiedy w połowie lat osiemdziesiątych zacząłem jeździć do Francji, korzystając z naukowych zaproszeń Alaina Touraine’a, a później także Renaud Sainsaulieu, byłem świadomy, że korzystam z zainteresowania Polską i Solidarnością. Żyłem tymi sprawami i dzieliłem się nimi z każdym, kto tego chciał. Należałem do trzeciej fali świadków. Pierwszą, nader liczną stanowili ci, którzy zdążyli wyjechać tuż przed stanem wojennym. Druga, byli polscy obywatele, którzy mogli wyjechać za granicę tuż po 1981 roku.

Były to zasadniczo dwie kompletnie odmienne grupy. Z jednej strony naukowcy i dyplomaci obdarzeni zaufaniem przez PZPR. Z drugiej - obywatele „pozbawieni zaufania” partii, którzy dostali paszport tylko w jedną stronę. $\mathrm{Na}$ ogół robotnicy i intelektualiści. Władze komunistyczne liczyły, że część solidarnościowych działaczy nigdy nie wróci i osiądzie za granicą. Tak się też stało. Byli to świadkowie szczególnie ważni, bowiem zdecydowana ich większość była boleśnie doświadczona przez represje,

\footnotetext{
${ }^{7}$ Jak donosiły media, 4 lipca 217 r. Lech Wałęsa dołączył do protestujących w Warszawie pod Sądem Najwyższym.

${ }^{8}$ Felieton TMCH \#17: Beczenie owiec, portal Kibice.net, https://www.kibice.net/publicystyka/133-felieton-tmch-17-beczenie-owiec.html.

9 Andrzej Friszke, mając świadomość narastających w Polsce podziałów politycznych, mocno rzutujących na odczytanie historii ruchu, napisał „Nie jestem całkiem bezstronnym historykiem tego czasu, uczestniczyłem w ruchu, który tu opisuje”. Dalej stwierdził, że uzyskany z czasem dostęp do archiwów i zawartych tam ocen z kręgu władzy nie zmieniły wiele w jego postrzeganiu fenomenu Solidarności. „Nie zmieniają one wiedzy ogólnej, która już wówczas dysponowaliśmy, pozwalają jednak na precyzyjne ich opisanie i datowanie”. A. Friszke, Rewolucja Solidarności 1980-1981, Kraków 2014, s. 18-19.
} 
które spadły na nich i ich rodziny. Ich przekaz łączył w sobie wiarygodność i rzeczywistą dramaturgię, pogłębianą jeszcze przez wewnętrzne podziały w łonie samego ruchu Solidarność ${ }^{10}$.

Trzecia fala świadków Solidarności, może uchodzić za mniej polityczną, a bardziej analityczną i reporterską. Sądzę, że mogę się do niej zaliczyć, jak wielu innych ludzi, którzy mogli wyjeżdżać za granicę w drugiej połowie lat osiemdziesiątych. Ta formacja zostawiła za granicą więcej dowodów swojej aktywności intelektualnej, aniżeli w Polsce. Była aktywnym środowiskiem świadków dopóty dopóki zainteresowanie Solidarnością było żywe ${ }^{11}$, przy czym odbiorcami naszej produkcji intelektualnej nie były miliony telewidzów lub czytelników, jak w latach 1980-1981. Uczestniczyliśmy w międzynarodowych konferencjach i seminariach, czasami organizując je również w Polsce. Jeśli z kolei mówić dzisiaj o czwartej fali, to będzie to już „drugie pokolenie” polskich historyków i coraz rzadziej socjologów ${ }^{12}$.

Trwające nadal badania związane z Solidarnością można podzielić na kilka grup. Pierwsze sa próbami odpowiedzi na pytanie ,jak było naprawdę?". Jest to domena poszukiwań prowadzonych przez historyków. Drugie podejście, chyba już zamknięte, koncentrowało się na budowaniu teorii, czym zajmowali się przede wszystkim socjologowie skupieni na ruchach społecznych, konfliktach lub zmianach, a także politolodzy i ekonomiści, zainteresowani zwłaszcza genezą „Solidarności”. Trzeci kierunek, zbliżony do drugiego, koncentruje się wokół hipotetycznych pytań o możliwe scenariusze dotyczące przeszłości i jest wiedziony pytaniem: „co by było gdyby?”. Dodajmy, że takie postawienie problemu wikła badaczy w spory natury światopoglądowej i politycznej, albowiem prowadzi do oceny działań aktorów społecznych, np. inteligencji lub doradców, którym przypisuje się odpowiedzialność za efekty przełomu 1989-1990.

Czwarty kierunek, to analizy następstw i skutków ruchu społecznego „Solidarność”, prowadzone w dwóch kierunkach. Jeden z nich ma charakter rzeczowo-opisowy i pokazuje zakres i rodzaje zmian wywołanych - jak niektórzy to nazywaja - „rewolucją Solidarności”. Drugi, podbudowany etycznie i filozoficznie, to dociekania pod hasłem: „co nam zostało w spadku po Solidarności?". Temu ostatniemu pytaniu towarzyszy przekonanie, że mamy do czynienia z cennym dziedzictwem, którego nie wolno zaprzepaścić. Warto w tym kontekście zacytować wypowiedź działacza, zarejestrowaną w 2010 roku: „Uważam, że jedynym sposobem upamiętnienia Solidarności jest to, co powinniśmy robić, żeby przestać być bezradnymi. Jednak im bardziej nie robiąc tego, będziemy stawiać jakieś pomniki - nie pomniki, tym bardziej będzie to fałszywe"13.

\footnotetext{
${ }^{10}$ Por. A. Znamierowski, Niezłomni. Solidarność Walczqca, Warszawa 2016.

${ }^{11}$ Dla odbiorców na świecie prawdopodobnie najważniejszym źródłem informacji były trzy prace wydane najszybciej, bo u progu lat osiemdziesiątych i dostępne w kilku językach, napisane przez Jadwigę Staniszkis, Timothy'ego Gartona Asha i Alaina Touraine’a z zespołem.

${ }^{12}$ Mam na myśli działalność Europejskiego Centrum Solidarności w Gdańsku, a także wieloletni projekt „Solidarność nowe podejście do analizy ruchu społecznego" realizowany konsekwentnie przez Mateusza Falkowskiego i Pawła Sowińskiego, a także projekt „Skarb Solidarności” realizowany w latach 2014-2015 przez Centrum Myśli Jana Pawła II.

${ }^{13}$ I. Krzemiński, Solidarność - doświadczenie i..., s. 341.
} 


\section{Zamiast podsumowania}

Chciałbym podzielić się poglądem, który może być bolesny dla uczestników Solidarności świadków bezpośrednich, do których również się zaliczam. Dla ograniczenia użyć i nadużyć dziedzictwa Solidarności skłaniam się do propagowania określenia „cenna pamiątka”, które dobrze oddaje potrzebę poznawczego dystansu wobec nieodległej przeszłości. Nie ma najmniejszych watetpliwości, że zmiany, które zainicjowała Solidarność, były fundamentalne, stąd przyjęło się określenie „samoograniczająca się rewolucja”. Choćby z tego powodu Solidarność musi być nadal przedmiotem badań historycznych, które wzbogacają naszą wiedzę o przeszłości. Jesteśmy to winni przede wszystkim działaczom zakładowym NSZZ Solidarność. To w zasadzie wszystko, co nam zostało $z$ tych lat.

Jest jeszcze jedna ścieżka. Prowadzi w przyszłość, z uwagą dla przeszłości. Odniesienie do Solidarności było użyteczne, i zapewne będzie nadal, dla liderów kolejnych ruchów protestu. Przy czym trzeba być świadomym, że ten fragment naszej historii najnowszej będzie odmiennie widziany przed działaczy różnych ruchów, tak w Polsce, jak i gdzie indziej. Liderzy STOP ACTA widzieli ruch społeczny Solidarność inaczej niż aktywiści ukraińskiego Majdanu ${ }^{14}$.
Jedni i drudzy potrzebowali tego punktu odniesienia, aby podkreślić, że ich protest jest inny $\mathrm{i}$ wyjątkowy. Uwzględniając te zmienne perspektywy warto pogłębiać wiedzę o solidarnościowym przełomie. Jego dogłębne zrozumienie pozwala liderom budować autorefleksyjną samoświadomość ruchów społecznych. W tej kwestii widzę nieco miejsca także dla refleksji socjologicznej. A jeśli idzie o nasz lokalny cmentarz narodowy, to trzeba na grobie ruchu społecznego Solidarność położyć ciężką, masywną płytę.

\section{Bibliografia}

T. Garton Ash, Polska rewolucja Solidarność, Londyn 1987

Felieton TMCH\#17:Beczenieowiec, portal Kibice.net, https://www.kibice.net/publicystyka/133-felieton-tmch-17-beczenie-owiec.html

A. Friszke, Rewolucja Solidarności 1980-1981, Kraków 2014

I. Krzemiński, Solidarność - doświadczenie i pamiés, Gdańsk 2010

Solidarność ikryzys zaufania, red. J. Kołtan, Gdańsk 2014

A. Znamierowski, Nię̧tomni. Solidarność Walczqca, Warszawa 2016

\footnotetext{
${ }^{14}$ Zainteresowanym polecam mój tekst Godność i prz̧emoc. Dekompozycja ruchu społeçnego Majdan, „Zoon Politikon” 2016, nr 7.
} 